\title{
Sztuczna wyspa Philip Bay
}

\section{Port Phillip Bay artificial island}

Streszczenie

Publikacja przedstawia współczesne metody rozwoju miast leżących nad wodą w oparciu o budowę sztucznych wysp. Re

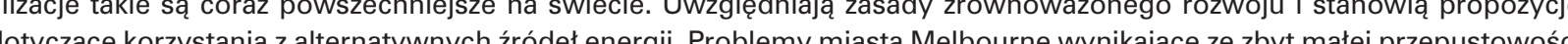
stniejacego portu mogłyby zostać zażegnane dzieki budowie w zatoce Philip Bay sztucznej wyspy. Rozwiazanie takie bylo proponowane przez władze miasta, nie doczekało sie jednak do tej pory realizacji. W publikacji przedstawiono projekt dyplomowy wykony na Wydziale Architektury Politechniki Krakowskiej, w którym uzasadniono potrzebe utworzenia sztucze wyspy w Philip Bay oraz zaprezentowano jej autorską wizje.

\section{Abstract}

The publication presents contemporary methods of the development of cities located near water on the basis of the construction of artificial islands. Such projects are becoming more and more common around the world. They take into consideration the precepts of sustainable development and constitute proposals concerning the use of alternative energy sources. The problems of the city of Melbourne, which are a result of its existing port's insufficient capacity, can be addressed through the construction of an artificial island on Port Philip Bay. Such a solution has been proposed by the city authorities, however it University of Technology in which the need to presentation of an original vision of such an island.

Stowa kluczowe: Szzuczna wyspa, Melbourne, rozwój miasta

\section{Wprowadzenie}

Wostatnich latach coraz bardziej popularne staje się na świecie zagadnienie dotyczące budowy sztucznych wysp. Przyrost ludności oraz zmieniający się klimat wymuszają niekonwencjonalne podejście do planowania przestrzennego oparte na nowych, ekologicznych wizjach miast. Krajem niezwykle pionierskim na różnych polach jest niewątpliwie Holandia. Od lat powstaja w niej na terenach podmokłych i przybrzeżnych nowe "inteligentne" technicznie inwestycje. Temat sztucznych wysp nie jest tu więc tematem obcym. Również w Zjednoczonych Emiratach Arabskich budowane są nowoczesne kompleksy o zaawansowanej technologii, zawierające ekologiczne rozwiązania, które lokowane są na sztucznych wyspach. Wyspy te, podobnie jak w Chinach, budowane z piasku i mieszanki ziemi wydobywanej z dna zbiorników wodnych, na których powstają. Pozwala to wykorzystać istniejące warunki i materiały oraz jest opłacalne finansowo. Nowoczesne sztuczne wyspy przedstawia się jako pływające obiekty. W idealistycznych wizjach futurystów często są samowystarczalne i moga znaleźć się na każdym otwartym zbiorniku wodnym. Projekty takie jak Lily Pad autorstwa Vincenta Calwodny proju niem noozo powstają też rzeczywiste realizacje. W Chinach budowana

Introduction

The issue of constructing artificial islands has bepome increasingly popular in recent years. Rising population numbers and climate change force us to adopt unconventional approaches to spatial planning, based on new, environmentally friendly
visions of cities. The Netherlands is a country the is, undoubtedly, a pioneer in various fields. New technologically "smart" projects have been built in its wetlands and coastal areas for years. The subject of islands is not an unfamiliar topic there. Modern, technologically advanced complexes featuring environmentally friendly solutions placed United Arab Emirates. These islands, similarly as in China, are being built from sand and a mixture of earth that is procured from the bottom of the water bodies that are the site of their construction. This makes it possible to utilise existing condition and materials, in addition to being financially prof-
itable. Modern artificial islands present themselves as floating structures. In the idealistic visions of futurists they are often self-sufficient and can be located on any open water body.

Designs like the Lily Pad by Vincent Callebau make it possible to show a game with architecture with the use of modern technologies'. Apart from carried out. An artificial island that is also being an energy generator using the energy of oceanic jest sztuczna wyspa, która ma być generatorem energii wy korzystuaacym energie prąów morskich oraz słonca. Dzięki takiemu rozwiazzaniu wzrasta znaczenie udział procentowy korzystania z odnawialnych źródeł energii. ${ }^{2}$ W 2018 roku ma rozpocząć się na Oceanie Spokojnym budowa nowej wyspy pływającej, przypominającej małe miasto. Ma ona się składać z pływających modułów połączonych ze sobą elastycznymi łączeniami. Uważa się, iż takie rozwiązanie zapobiegnie uszkodzeniom wynikającym z pływów morskich i ruchów fal. Na wyspie mają się znaleźć przestrzenie publiczne, budynki mieszkalne, usługowe, szkoły, transport zbiorowy. Opracowany jest również system poboru energii z odnawialnych źróde oraz oczyszczalnie słonej wody i ścieków. ${ }^{3}$ Nowa technologia Ocean Thermal Energy Conversion ${ }^{4}$ polega na wykorzystaniu dużych zmian temperatury przy powierzchni wody i na dnie zbiornika do produkcji energii. Różnica temperatur około 20 stopni pozwala osiągnąć znakomite rezultaty. Generowana energia moze byc przesyłana do modułow mieszkalnych na wyspie, bądż do sąsiednich miejscowości. Współczesne możliwości technologiczne i materiałowe pozwalają na niestandardowe rozwiązania, dzięki którym można sprostać rosnącym wymaganiom dotyczącym warunków technicznych ekologii, problemu przeludnienia, zmian klimatycznych.

\section{Melbourne - „Fluid City”}

Miasto Melbourne leży nad zatoką Philip Bay, przy ujściu rzek Yarra. Panuje tu klimat przejściowy morski charakteryzujący się dużą wilgotnością i znacznymi dziennymi wahaniami temperatur. Założenie miasta przez grupę wolnych osadników pod przewodnictwem Jana Batmana datowane jest na 30 sierpnia 1835 roku. ${ }^{5} \mathrm{Na}$ początku XX wieku Melbourne pełniło funkcję stolicy Australii, a już w latach 80-tych dotkna go kryzys ekonomiczny i przemysłowy. Aby odbudować nadwyrężony wizerunek miasta podjęto decyzję o zwróceniu go w stronę wody. Program naprawczy obejmował rewitalizację terenów nadbrzeży - Yarra River, Melbourne Dockland i Port Philip Bay. Melbourne, określane jest jako "fluid city". Płynność dotyczy tu przepływu: ludzi, różnych środowis etnicznych, imigrantów, turystów, informacji, technologii, kapitału, nowych idei. „Fluid city” pozwala traktować to miasto jako płynny koncept, uzależniony od otaczajacej je wody, geologii, historii, wydarzeń, wspomnień, projektów. Poza struktura urbanistyczna, najwiekszy wpływ na poczucie miejsca, jego granic i funkcii ma zespót płynnych ruchów miejsca, jego granic i funkcji ma zespol plynnych ruchow przekształcania miasta zwrócono zatem szczególną uwage

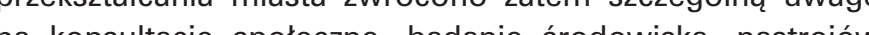
na konsultacje spolecze, bdanie srodowiska, nastrojow w oparciu o nabrzezza rzeki, portu oraz zatoki. Rewitalizacja brzegów rzeki zmienila obraz miasta, stworzone zostały interesujące przestrzenie przyciągające zarówno mieszkańców jak i turystow. Dwiescie hektarow przestrzeni portowych w zachodniej czesści miasta wciąż podlega przekształceniom opartym o potrzeby rynku oraz plany urbanistyczne. Cztery kilometry plaż i terenow miasta położonych najbliżej wód zatoki to poważne zadanie dla planistów, przy uwzględnieniu rozwi- currents and that of the sun is being built in China. Thanks to such a solution, the percentage share the use of renewable energy sources will increase ${ }^{2}$. Constriction lo to commence on a new floating is in 2018. It is meant to be composed of floating modules connected with elastic joints. It is believed that such a solution will prevent damage from tides and the movement of waves,

The island is to feature public spaces, residential and An energy generation system and public transporenergy sources, as well as the purification of seaweter and waste is being developed as well3. The new Ocean Thermal Energy Conversion ${ }^{4}$ technology is based on using significant temperature shifts near the surface and on the bottom of a water body to produce energy. The temperature difference, which excellent results. The energy generated by the system can be directed to residential modules on the island or to neighbouring localities. Contemporary technological and material capabilities make it possible to utilise non-standard solutions, thanks to which we can meet the growing demands concernoverpopulation and climate change.

Melbourne - „Fluid City"

The city of Melbourne is located near Port Philip Pay, near the mouth of the Yarra River. It has a tenhigh humidity and significant daily fluctutions in temperature. The founding of the city by a group of free settlers under the leadership of John Batman was dated to 30th August 18355. In the beginning of the twentieth century Melbourne played the role Australia's capital, while in the 1980's the city was affected by an economic and industrial crisis. made to orient it in the direction of the water. The repair programme covered the urban regenera-
tion of waterfronts the Yarra River, Melbourne Docklands and the Port Philip Bay, described as a "fluid various Thiffenty is atributed the flow of people, various different ethnic groups, migrants, tourists, "fluid city" makes it possible to treat the city like a fluid concept, dependent on the surrounding water, geology, history, events, memories and projects. Apart from the urban structure, the greatest influtice on the feel of the place, its borders and funclions, is exerted by a system of fluid movements experiences. Particular attention during the transformation of the city was thus paid to public consultations, investigating the environment and the opinion of the residents. It was decided that the necessary wanges should be introduced on the basis of the waterfronts of the river, the port and the bay

政 ing both residents and tourists being created. Two hundred hectares of port spaces in the western part of the city are still being subjected to transformaplans. The four kilomes of plans. The four kilometres of beaches and areas of constitute a significant challenge to urban planners 
jającej się tkanki urbanistycznej, metropolitalnego znaczenia Melbourne oraz wa nnkow wodno-srodowiskowych. W roku 1989 premier John Cain wskazał na potrzebe zwrócenia miasta w stronę wody, która według niego symbolizuje matke, do której większość z nas chce powrócić, a w jej ulewnym lub burzliwym aspekcie, również symbolizuje ojca. 7 Wielkim wyzwaniem dla miasta staty sie zwhaszcza dawne tereny portu zomittee for Melbourne, grupa z toziona z dzia zacy cy portu. Comich wem sekra publczego i kywaty wem sekto publiczego i prywang, ke wala doborem strategii planowania przestrennego terenow portowych. Za podstaw raważan na ten temat uznano teorie Kevina Lyncha oraz Jane Jacobs dotyczące mieszania funkcji, skali ludzkiej, trwałości i żywotności przestrzeni. Propozycje MultiFunction Polis z koncentracją wysokich technologii, planem utworzenia nowego miasta o zaawansowanym, nowoczesnym programie z lotniskiem i szybkim dostępem komunikacja miejską przedstawione przez Comittee for Melbourne okazały się jednak wizją idealnego miasta, która nie została spełniona. W późniejszych latach powstało kilka ważnych planów rewitalizacji całej przestrzeni (Conceptual Planning and Design Framework and Visions 1996, Vision of Winning Bids 1997). Ukończone zostały częściowe przekształcenia, w tym plan CityLink z 1995, Docklands Village propagujacy powstawanie terenow mieszkaniowych. Utworzony zostat park biznesowy, technologiczny przestrzen publiczna wraz ze stadionem Docklands Stadium oraz atrak pynmi bulwazami przy bregu. Gęstość i różnorodność przestrzeni społecznych pełnia funkcje cywilizacyina, przyczyniaja sie do rosnacej tolerancji na różnice, umożliwiając formację nowych jednostek identyfikujących. ${ }^{8}$ Projektowanie zgodne $z$ tą tezą pomogło zrewitalizować obraz Melbourne jako miasta nowoczesnego, wy korzystującego potencjał swojego położenia. Aby umożliwić rozwój metropolii istnieje potrzebne jest niekonwencjonalne podejście do przestrzeni portowych największego miasta stanu Victoria.

Kiedy w XX wieku Sydney zyskało silne znaczenie, Melbourne pogrążone było w kryzysie gospodarczym. Rewitalizacja przestrzeni portowej Sydney i budowa opery witającej podróżujących drogą morską, bardzo pozytywnie wpłynęły na ekonomię, turystykę i poziom życia w mieście. Sydney przyjmuje rocznie ponad 250 statków pasażerskich. Turyści wspieraja ekonomie miasta, lokalny biznes, sprzyja to również pozytywnemu wizerunkowi miasta. Turystyka morska jest tu niezwykle popularna lnaczej w Melbourne Spowodowane jest to brakiem czytelnej panoramy miasta od strony zatoki, trwajacymi pracami nad uatrakcyjnieniem brzegu, a zwłaszcza portem nieprzystosowanym do przyjeccia wiekszej liczby statków. W 2016 roku miasto musiało zrezygnować z przyjęcia największego na świecie statku Ovation of the Seas o długości $348 \mathrm{~m}$ i 18 piętrach wysokości, mogącego pomieścić ponad 6000 pasażerów. Wizyta takich statków mogłaby pozytywnie wpłynąć na ekonomię miasta. Brak przystosowania portu Melbourne dla nowoczesnych wycieczkowców jest postrzegana jako niewykorzystanie potencjału miasta. Plany rozbudowy przestrzeni portu uznawane są za bardzo potrzebne, lecz żadne when taking into consideration the developing urban tissue, the metropolitan significance of $\mathrm{Me}$ ditions. In 1989 prime minister $J$ vironmental conto the need to orientate the city in the direction of the water, which, according to him, symbolises a mother to which most of us want to return to, and in its torrential or stormy aspect, also symbolise a father?. The former port grounds turned out to be particularly significant challenge for the city. The vilian activists and contro, a group composed of $\mathrm{ci}$ with a small degree of influence from the public and private sector directed the selection of the strategy of the spatial planning of the port grounds.

The theories by Kevin Lynch and Jane Jacobs concerning the mixing of functions, the human scale, resilience and vitality of a space were adopted tions of the Multi-Function Polis with a concentration of advanced technologies and a plan of the establishment of a new city with an advanced modern programme featuring an airport and rapid public transport presented by the Committee for city that was not implemented. During later idears a number of important plans of the regeneration of the entire area were developed (Conceptual Planning and Design Framework and Visions 1996 Vision of Winning Bids 1997). Partial transformalions, including the Citylink plan of 1995 and the Docklands Village, propagating the establishment and technological park, along with a public space and the Docklands Stadium, in addition to attractive boulevards near the shore, were built. The density and variety of social spaces play a civisational function, leading to a growing tolerance for diversity, enabling the formation of new identi-
fication units? sis helped to revitalise the image of Melbourne as a modern city, one that makes use of the potentia of its location. In order to enable the developmen of the metropolis, an unconventional approach to

When Sydney gained considerable significance weighed down by an economic crisis. The regeneration of the port spaces of Sydney and the construction of the opera building that greeted those visiting the city by sea affected the economy, tourism and the quality of life within the city
very positively. Sydney takes in over 250 cruise ships every year. The tourists support the city's economy and the local businesses, in addition to aiding the positive image of the city. Marine tourism is exceptionally popular here. Contrary to the situation in Melbourne. This is caused by the lack of a legible skyline of the city from the side of the attractive, and primarily by the fact that the port is not adapted to a larger number of ships. In 2016 the city had to decline to accept the largest ship in the world, Ovation of the Sea, with a length of 348 Visits by su

ins could positively affect the
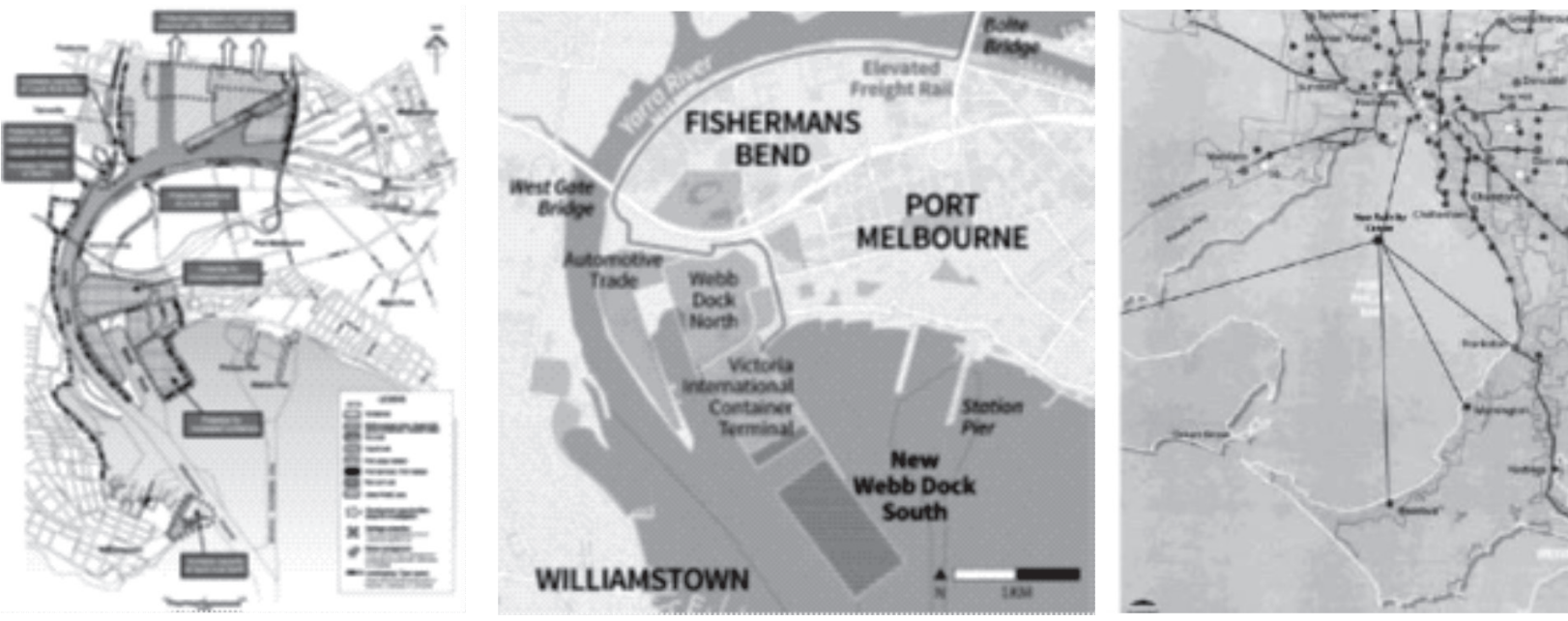

III.1 a) Planowane przeksztatcenia portu w Melbourne. Uwaga skierowana głównie na duż port transportowy, kontenerowy, íródto: Victoria
Harbour Docklands Conservation Management Plan. Places Victoria \& City of Melbourne. 2012; b) Koncepcja budowy sztucznei wyspy jako ko ka -sale-value-20151119-gli30n55.hthl; c) Koncepcja budowy sztucznej wyspy jako nowego portu ogloszona przez Burmistrtza Melbourne w 2016 roku, źródło: http://www.heraldsun.com.au/news/victoria/manmade-island, dostęp: 20.08.2018 作

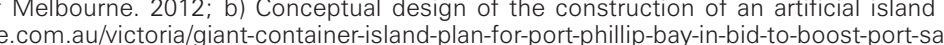
-value-20151119-|l|30n5.html; c) Conceptual design of the construction of an artificial island as a new port, published by the Melbourne Mayor

z proponowanych wczesniej rozwiązań nie zostało w pełni zadoki przeznaczone w więszosci dla stakow transportowych i składowania kontenerów. W 2013 roku ogłoszono ramowy plan urbanistyczny Port Melbourne Waterfront, zakładający przebudowe Station Pier, portu transportowo-wycieczkowego. Nie przewidziano tu jednak potrzebnej rozbudowy i poszerzenia. Port ten znajduje się w strefie zabudowy mieszkaniowej wielo- i jednorodzinnej. Nie jest to sprzyjający czynnik

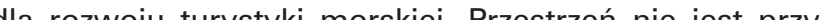

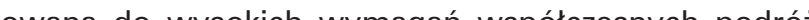
ma dziś jest zatem stworzenie obszernego portu, mającego świadczyć podstawowe usługi, przyciągać turystów, ale i lokalnych mieszkańców zróżnicowana funkcją. Mimo, iż powiększono techniczny port przeładunkowy, wciąż jest on zbyt mały. Plany rozwoju Melbourne Waterfront Metropolitan Melbourne, Melbourne 2030, Melbourne 2017 2050 zakładają silny rozwój metropolitarny miasta w oparci o ideę zrównoważonego rozwoju

W grudniu 2016 roku burmistrz Melbourne, Robert Doyle, ogłosił zaskakującą koncepcję rozwoju turystyki morskiej stolicy Victoril. Proponowana przez niego sztuczna wyspa, utworzona w zatoce Port Philip Bay miałaby miescic duzy port dla miasta, a także być nowym symbolem zatoki, przyciągać turystów. Statki wycieczkowe są coraz większe, więc przy obecnym stanie portu miasto nie jest $w$ stanie sprostać rosnącym wymaganiom, co może skutkować zahamowaniem rozwoju Station Pier, wg burmistrza był nieatrakcyinym punkte jazdowym, majacym bardzo duż limity i ograniczenia Pro- bourne's port to modern cruise ships is seen as not the expans loge of the city's potential. The plans of needed, however, none of the solutions that had been proposed earlier were accepted. The current development strategy covers existing docks, which mostly provide servicing for cargo ships and shipping container storage. In 2013 a framework urbaplan was introduced for Port Melbourne, which feaport and cruise port. However, the necessary expansion and broadening were not included within it. The port is located in a multi and single-family residential zone. It is not a factor that supports the growth of marine tourism. This space is not rary travellers. The current challenge is thus the establishment of a spacious port that is meant to provide basic services, attract tourists as well as local residents through its varied functions. Despite the technical cargo port being expanded, is still too small. The Melbourne Waterfront, Met2017-2030 development plans assume a strong metropolitan growth of the city based on the idea of sustainable development?.

In December 2016 the mayor of Melbourne, Rober Doyle, proclaimed a surprising concept of develortificial island that he proposed, to be built in The Philip Bay, would house a large port, in addition to constituting a new symbol of the bay, attracting tourists. Cruise ships are getting increasingly large which is why under the port's current condition the city is incapable of meeting the increasing expectations, which can lead to a halt in development. Staarival point, having many limits and constrints. The 
poza możliwości miasta i wyobrażenia mieszkańców, jednak Melbourne. W 2004 roku Infrastructure Victoria udosteppito do publicznej dyskusji plany wysp z przeważająca funkcja mieszkalna wzdłuż brzegu Port Philip Bay. Projekty Bay West i Hastings kosztowałyby około 3 biliony dolarów. Wyspy miaty mieć wła zne zasoby wody i energii pozyskiwanej rómniez

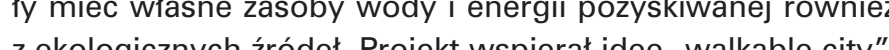
zromujac ruch pieszy i row wany. W 2015 roku zaproponowano skonstruowanie wielkiej wyspy o charakterze industrialnym w ujściu rzeki Yarra, jako przedłużenie istniejącego portu.

Dobra strategia Melbourne polegająca na skierowaniu jego rozwoju miasta w stronę wody, pomogła odbudować nieco jego pozycję. Nowe plany rozbudowy portu są bardzo istotne, co pokazują koncepcyjne projekty formułowane na przestrzeni lat. Victoria zainkasowała w latach 2014-2015 sto sześćdziesiąt jeden milionów dolarow w związku z turystyką wodną. W tym samym czasie Nowa Południowa Walia, ktorej stolica jest Sydney zdobyła 1,87 bilionów dolarów. Melbourne potrzebuje dobrego planowania, aby móc rozwijać się na arenie międzynarodowej. Koncepcja sztucznej wyspy, popierana przez burmistrza Roberta Doyle'a jest wyzwaniem kryjacym w sobie wielki potencjał.

\section{Sztuczna wyspa dla Melbourne}

Odpowiedzią na koncepcję burmistrza Roberta Doyle'a jest projekt dyplomowy wykonany na Wydziale Architektury Politechniki Krakowskiej. Jest to projekt sztucznej wyspy w zatoce Philip Bay z nowym portem oraz oceanarium, pełniącym również funkcje edukacyjno-badawcze. ${ }^{10}$

Turystyka ma bardzo duży wpływ na ekonomię w Australii, zwłaszcza turystyka wodna. Melbourne, jedno z największych miast kontynentu, odwiedzają rocznie osiemdziesiąt cztery statki. Sydney przyjmuje w tym czasie trzysta osiem wizyt $w$ porcie. Statystyki te nie wywodzą się z braku zainteresowania miastem Melbourne, lecz z braku możliwości przyjęcia tak dużej liczby statków przez dostępne porty. Brak odpowiedniego zaplecza portowego znacząco hamuje rozwój zatoki Port Philip Bay. Melbourne posiada największy port przeładunkowo-magazynowy kontenerów w Australii. Duże statki ładunkowe docierają tu i obsługiwane są przy ujściu rzeki Yarra do zatoki. Port turystyczny znajduje sie w południowej cześci miasta oddaloj od centrum miasta cofnietego w gab ladu do którego nie ma bezpośr dniego dostepu z zatoki. Przaby wajacy do Melbourne waku jo Mi joun doku, jaki stanowi miasto nadbrzeźne. Promy pływające po Devonport są powolne. Innych publicznie dostępnych potąDevonport są powolne. Innych
czeń morskich w zatoce brak.

W Melbourne występuje dużo zielonych przestrzeni publicznych. Zapotrzebowanie na parki, przestrzenie rekreacji i sportu zostało uwzględnione w planach projektowych. Istotnym elementem kompozycji urbanistycznej jest historyczne centrum miasta w kształcie prostokąta. Znajdują się tu dominanty kompozycyjne w postaci budynków wysokościowych, proposal can appear too progressive and going beyond the city's capabilities, as well as the resident expectations, however, this is not the first propos concerning an articial island for Melbourne.

in 2004 infrastructure Victoria submitted plans of along the shore of Port Philip Bay for public discussion. The Bay West and Hastings projects would cost around 3 billion dollars. The islands were to have their own water and energy stores obtained ect backed the idea of a "walkable city" promot ing pedestrian and bicycle traffic. The project was not carried out. In 2015 the construction of a large island with an industrial character at the mouth of the Yarra River was proposed, in order to serve Melbourne's good strategy, based

development of the city towards the water, helped somewhat in restoring its position. The new plans of the extension of the port are essential, which has been shown by conceptual designs that have been formulated throughout the years. Victoria gained 2014-2015. During the same time, New South Wales, whose capital is Sydney, gained 1,87 billion dollars. Melbourne needs good planning in order to be able to develop at the international level. The concep of an articial island, supported by mayor Rober

An artificial island for Melbourn

One answer to mayor Robert Doyle's idea is a Master's project developed at the Faculty of Architecture of the Cracow University of Technology. It is a design of an artificial island in Philip Bay, with educational and scientific role $e^{10}$.

Tourism has a significant impact on the economy in
Australia, particularly marine tourism. Melbourne one of the largest cities of the continent, is visite by eighty four ships per year. Sydney registers thre timafram and eight visits to its port within the sam of interest in the city of Melbourne, but rather of a lack of the capacity to accept such a large number of ships by available ports. The lack of appropriate port infrastructure significantly constrains the development thort Philip Bay. Melbourne has the largest cargo ships are serviced at the mouth of the Yarra River, at the point where the river enters the bay. The tourist port is located in the southern part of the city, placed further away from the city centre, which is further inland, and to which there is no direct access have an attractive view in the form of a waterfront city. The ferries that sail along the Yarra River and which provide access to Williamstown and Devonport are quite slow. There are no other publicly available marine connections in the bay. There is a large number of green public spaces in sports spaces has need for parks, recreational an the design plans. A significant element of the $u$ ban composition is the historical centre of the city, which is shaped like a rectangle. It features com positional landmarks in the form of high-rise build-

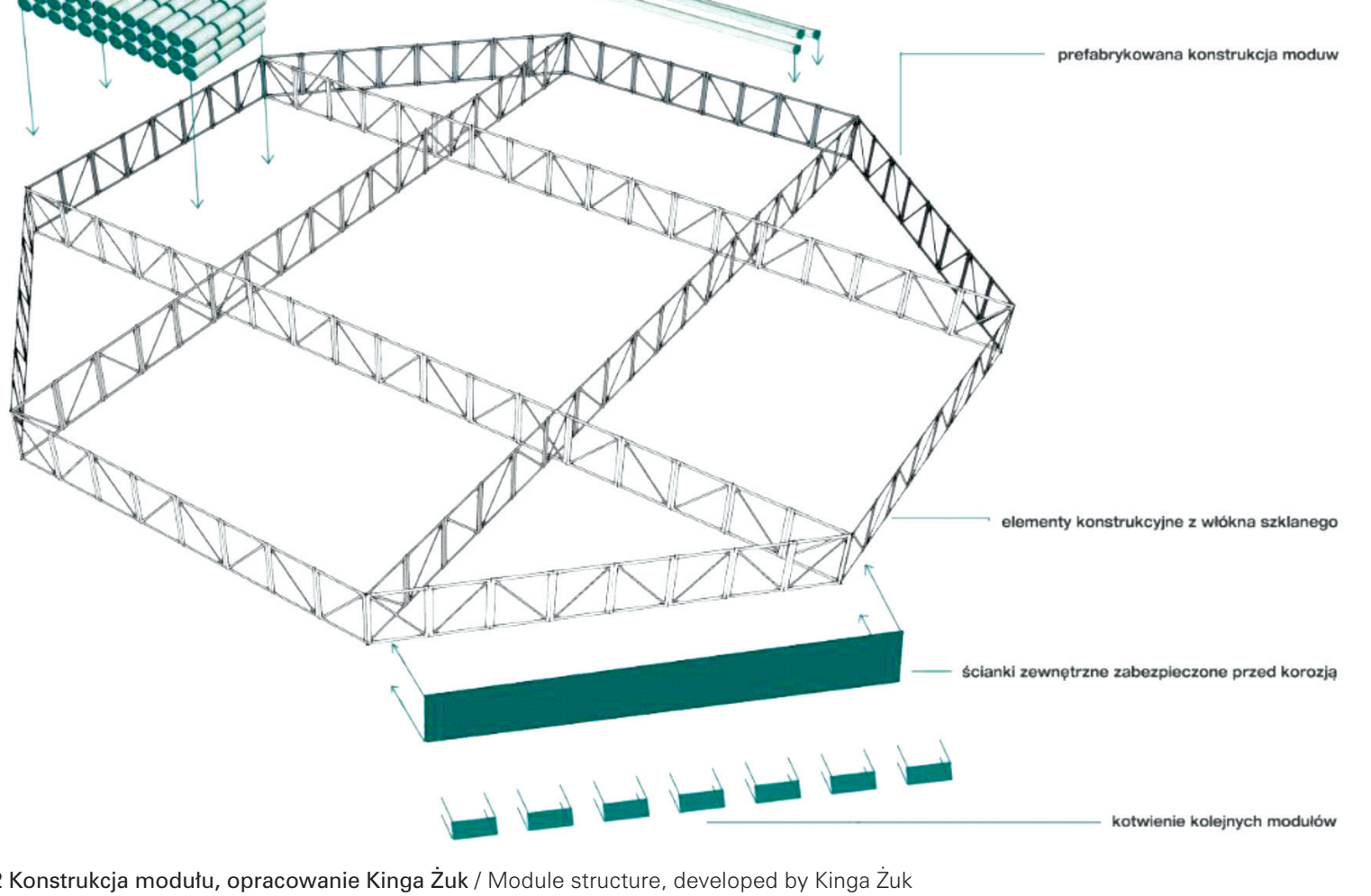

widocznych wyraźnie z każdego punktu miasta i przedpola miasta od strony zatoki Port Philip. $Z$ centrum do pomostu portu turystycznego wiedzie os kompozycyjna wyznaczon przez zieloną aleję. Druga os prowadzi od parku sportowego do zatoki Port Philip. Ze względu na położenie, stopień rozwoju miasta i potrzebę utrzymania istniejącej struktury urbanistycznej, po analizie uwarunkowań lokalizacyjnych, ekonomicznych i badaniach dotyczących turystyki wodnej, podjęto probe stworzenia koncepcil pływającej wyspy, ktora miałaby pomieścić wymagane funkcje, nie niszcząc przy tym dna morskiego i dostosowując się do zmieniających sie potrzeb. Projektowana sztuczna wyspa ma być centralnym ośrodkiem zatoki Port Philip Bay, do którego dopływać beda turystyczne statki pasazerskie, jak i prywatne todzie. Potaczenia wyspy z najważniejszymi miastami odbywać sie maja za pomspy szybkich promón. Wyspa zosta zaprojektowana womoca zzy szic ad centrum Melboune osiem kilomerow. Może byc więc latwo skomunikowana droga wodnal z miastem i okolicam W miejscu, gdzie przedłuzenie głównej osi przecina się z osia prowadzącą od widokowej ulicy i centrum sportowego, za proponowano budynek oceanarium.

Wyspa składa się z modułów, co umożliwia modyfikacje w przypadku zmian dotyczących potrzeb miasta. Elastyczne połączenia modułów zapewniają naturalne poddawanie sie struktury ruchom fal morskich. Takie rozwiązanie może zapobiec ewentualnym uszkodzeniom i problemom ze stabilnością konstrukcji. Moduły dołączane są niezależnie. Produkcja i montaż prefabrykowanych części może odbywać się na terenie portu towarowego Melbourne. Wyspa opiera sie na zasadach wynikających z idei zrównoważonego rozwoju. Ruch samochodowy jest ograniczony do minimum. Dopuszcz sie tam jedynie pojazdy techniczne obsługi oceanarium i portu. the city, as well as from the foreground of the city
from the side of Port Phillip Bay. There is a compositional axis outlined by Bay. There is a com runs from the centre to the terminal of the tourist port. The second axis leads from the sports park to Port Philip Bay. Due to the location, the degree of the development of the city and the need to mainan the existing urban structure preceded by an as well as studies concerning marine tourism an attempt was made to develop a conceptual design of a floating island, which could house the necessary functions, while causing no damage to the sea floor and adapting to changing needs.

The artificial island featured in the design is mean to be the central point of Port Phillip Bay, meant to The connections between the island and the most important ports are meant to be provided by rapidtransit ferries. The island was designed at a distance of four and a half kilometres from the current tourist port and eight kilometres away from Melbourne's downtown area. It can thus be easily connected ing areas. An oceanarium building has been proposed in the area where the extension of the main axis crosses the axis leading from the viewing stre and the sports centre. The island is composed of modules, which enables its modification in the case of changes arising from the city's needs.

the ment of the waves. Such a solution can prevent possible damage and problems with the structure's stability. The modules are joined independently. The production and assembly of prefabricated parts can take place on-site at the Melbourne cargo the idea of sustinable development Vehicular trom fic has been limited to a minimum. Only vehicles belonging to the technical services of the ocean- 


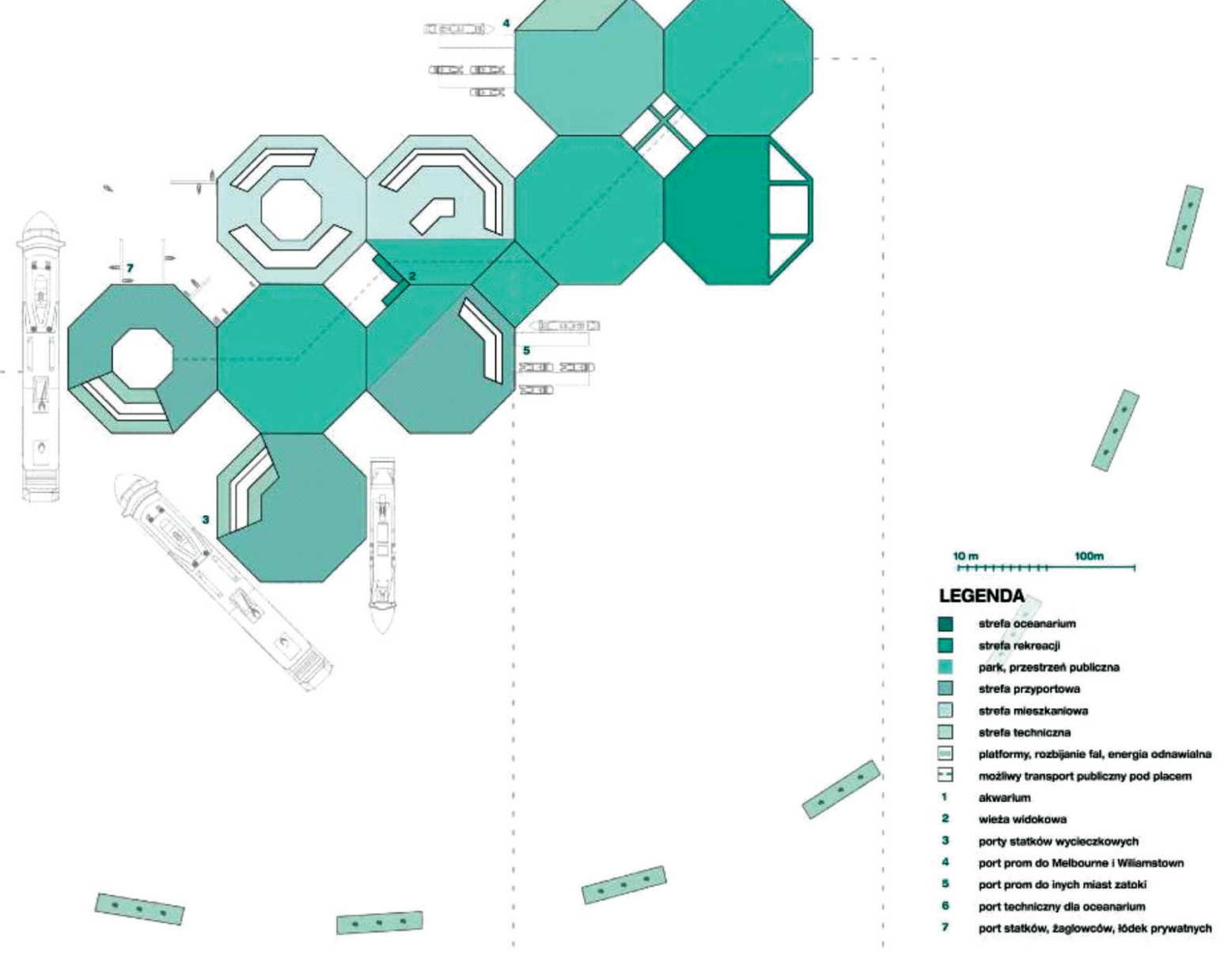

II. 3. Schemat funkcjonalny wyspy opracowanie Kinga Żuk / Functional scheme of the island. Developed by Kinga Żuk

Możliwy jest transport zbiorowy za pomocą metra umieszczonego pod powierzchnią placów zewnętrznych. Celem projektu jest zapewnienie przestrzeni przyjaznej dla ludzi, stymulującej do działania i eksploracji świata.

Kształt modułu oparty jest na ośmioboku. Taki kształt pozwala na utrzymanie stabilności statycznej konstrukcji przy projektowanych dużych wielkościach modułu. Zaproponowany bok modułu ma długość siedemdziesiąt dwa metry. Prefabrykowana konstrukcja w postaci kratownicy wykonana jest $z$ bardzo wytrzymałego włókna szklanego. Ściany zewnetrzne oraz dno modułu wyłożone jest płytami $z$ włókna szklanego zabezpieczonymi dodatkowo przed działaniem wody morskiej. W przestrzeni wewnetrznoj znjduja sie ptywaki, kóre maja Waprzwić wyporność i unoszenie sie wyspy na powere maja zapew Kc wyp wosci i noszie sie wyspy na powierzchn wody. Kazdy mod wy stem mocowa mia aby podhacz je i mody wyspy moglo być wykonywane sprawnie iefektywnie. Modu oceanarium oraz wieza widokowa zakotwione sa $\mathrm{w}$ grunci poprzez system pali i obręczy, Które mogą się podnosić. Analiza istniejących uwarunkowań pozwolita na przedstawienie założeń programowych i najważniejszych funkcji potrzebnych na wyspie, która ma stać się głównym portem zatoki. Mają się tu znaleźć: strefa portu dla statków pasażerskich, wraz z potrzebną infrastrukturą, strefa techniczna ze spalarnia śmieci, systemami energii i odsalania wody słonej. Środkowa część wyspy przeznaczona jest na strefę mieszkalno-hotelowa. Wschodnia część stanowi park rekreacyjno-sportowy z najbardziej wysuniętym na północ modułem oceanarium. Zaprojektowane zostały również dwa porty promów, port arium and port are to be allowed. Mass transport is possible through the use of an underground
rail placed underneath the surface of the external squares. The goal of the design is to provide a space that is friendly to people, that stimulates us to be active and to explore the world. The shape of the module is based on an octagon. Such a shape makes it possible to maintain the of the large size of the modules. The proposed side of the module has a length of 72 metres. The prefabricated structure in the form of a truss will be made out of very durable fibreglass. The external walls, as well as the bottom of the module, additionally proofed against the effects of seawater. The internal space will contain floaters, which are meant to ensure buoyancy and that the island stays on the surface. Each module is also fitted with a special joining system, in order for the conto be performed appropriately and effectively. The oceanarium module and the viewing tower are anchored to the ground through a system of piles and girdles, which can move vertically. An analysis of the existing conditions made it possible to presen portant functions required on the island, most im to become the main port of the bay. It is to include: a port zone for cruise ships, along with the necessary infrastructure, a technical zone with a thermal waste processing plant, energy generation and seawater desalination systems. The central part and hotel zone. The eastern part constitutes a park with recreational and sports grounds, along with

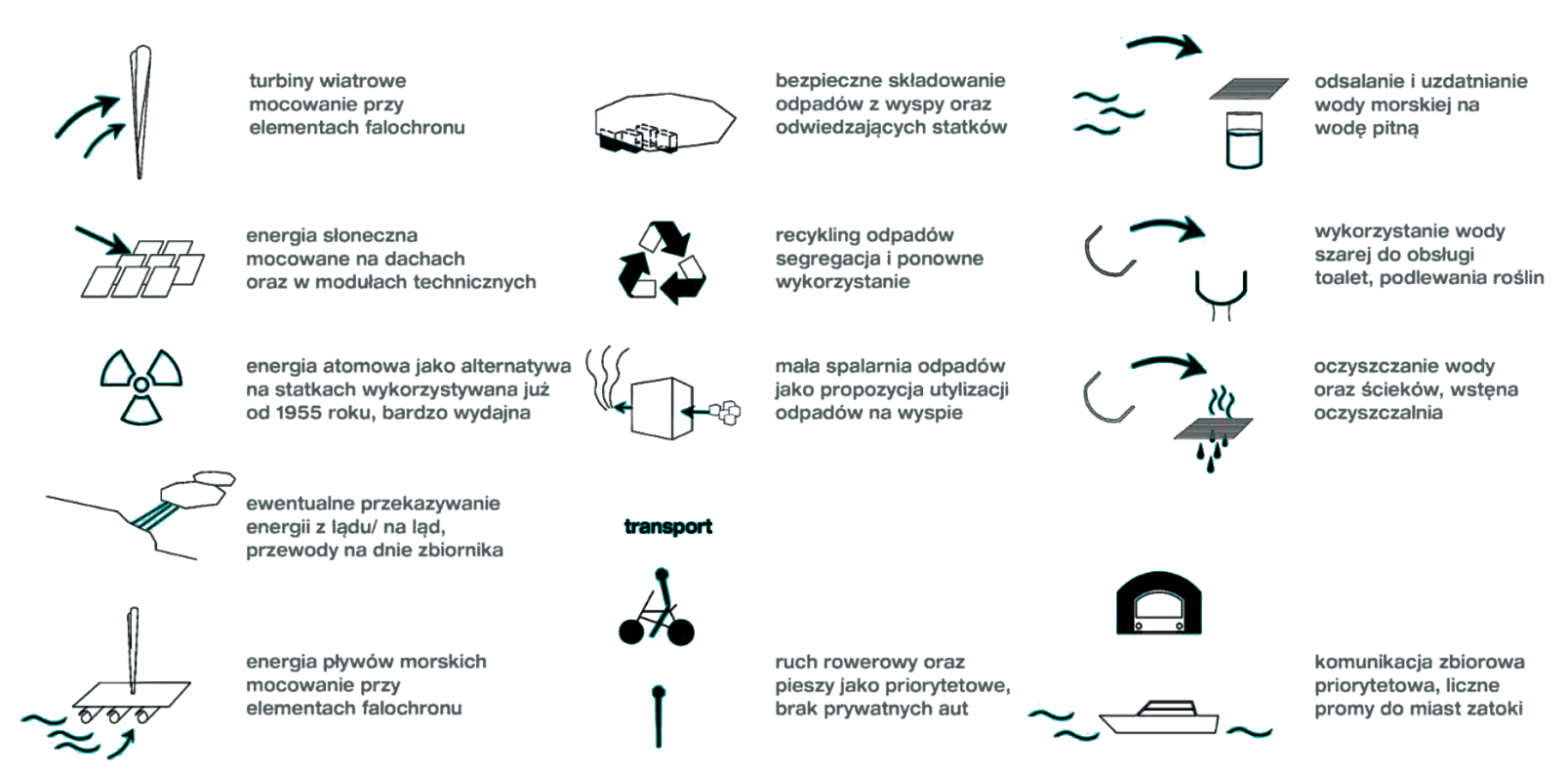

II. 4. Ideowe przedstawienie technologii, które moga być wykorzystane w projekcie wyspy pływajacej opracowanie. Kinga Żuk
III. 4 . Conceptual presentation of the technologies that are to be used in the design of the floating island. Developed by Kinga Żuk

echniczny oraz port łodzi prywatnych. W założeniu, wyspa ma sie składać $z$ jedenastu modułów początkowych. Możliwa jest ich multiplikacja w zależności od potrzeb. Na wyspie zaproponowano wykorzystanie m.in. energii wiatru za pomoca turbin wiatrowych mocowanych przy elementach falochronu energii słonecznej, energii pływów morskich.

\section{Podsumowanie}

Od drugiej połowy $\mathrm{XX}$ wieku mamy do czynienia z realizacja szeregu rozwiazzń zwiazanych $z$ rewitalizacja i reintegracja regracja , pozala kształtować niezwykle pożądane przestrzenie rekreacyjne na wolnym powietrzu. ${ }^{11}$ Słynna organizacja Project for Public Spaces ${ }^{12}$ za szczególna wartość w przestrzeniach miejkich uznaje kontakt z woda. Atrakcyjna przestrzeń przyciąga mieszkańców i turystów a nadbrzeza nadają wielu miastom ciekawy i niepowtarzalny charakter. Badania nad współczesnymi nadbrzeżami pozwoliły wyłonić czynniki sprzyjające wysokiej ocenie tych przestrzeni. ${ }^{13}$ Tereny nadbrzezy nie moga być zdominowan przez założenia mieszkaniowe, bowiem wysoka koncentracja funkcil mieszkniowej uniemozlliwitaby nocne życie tych przestrzeni, organizacje imprez o podwyższonym natężeniu hałasu. Całodobowa aktywność nadbrzeży przez cały rok sprzyja ich pozytywnemu obrazowi przynoszac przy tym korzyści ekonomiczne i społeczne. Obszary te musza być łatwo adaptowalne do zmieniających się potrzeb i warunków. Ważne jest również dostosowanie ich do wymagań różnych rup społecznych: dzieci, młodzieży, dorosłych jak również osob starszych. Aby kazda z grup mogła z łatwością korzystac z przestrzeni niezbędne jest dobre połączenie zarówno transportem osobowym, miejskim, jak i wodnym. Woda przyciaga ludzi, jest znaczącym czynnikiem podnoszącym atrakcyj- the oceanariaum module, which is located the furthest to the north. Two ferry ports have also been
designed, as well as a technical port and a port for private vessels. Overall, the island is meant to be composed of eleven initial modules. It is also possible to multiply them should the need to do so arise. Making use of, among other types, win the use of wind turbines mounted near elements of the breakwater, in addition to solar energy and tidal energy.

Conclusions

Coce the second half of the twentieth century we of solutions associated with the urban regeneration and reintegration of urban waterfront areas. Offering cities direct contact with water, which was often lost as a result of the development porms of use associated with ports, makes ational spaces 1 . The famous organisation Project for Public Spaces ${ }^{12}$ considers contact with water as a highly significant value in urban spaces. An attractive space causes residents and tourists to gravitate towards it, while waterfronts provid many cities with an interesting and unique charit possible to identify factors that are conducive to the high rating of these spaces

Waterfront areas cannot be dominated by residential layouts, because a high concentration of residential forms of use would make nightlife an these spaces impossible. The day and night activity of waterfronts throughout the entire year aids in their positive perception, bringing with it economic and social benefits. These areas must be easily adaptable to changing needs and conditions. It is ant social groups: childrem to the needs of diffe as seniors. In order for each of these groups to be able to easily make use of these spaces it is nece- 
ność nadbrzeży, jednak przestrzeń publiczna często wymaga stworzenia pewnej tożsamości, łatwego do zapamiętania czynnika wyróżniającego. Identyfikacji może sprzyjać ciekawy projekt urbanistyczny, mała architektura, oświetlenie lub budynek-ikona. Wszystkie te czynniki wpływają na odbiór przestrzeni, jej atrakcyjność i stopień wykorzystania potencjału lokalizacji danego miejsca. Nowoczesne konstrukcje sztucznych wysp pozwoliły na taki właśnie rozwój terenów nadbrzeżnych i stworzenie ikonicznego obrazu miasta, który otwiera się przed napływającymi do portu statkami. Wydaje się, że odpowiadająca na powyższe wyzwania sztuczna wyspa w Philip Bay pozwoliłaby zyskać nową jakość również miastu Melbourne.

\section{PRZYPISY}

${ }^{1}$ vincent.callebaut.org/ (dostep 21.03.2018)

2 Lily Pad futurystyczne pływające miasto autorstwa Vincenta Callebaut http://inhabitat.com/lilypad-floating-cities-in-the-age-of-global-warming (dostęp 21.03.2018)

3 Artisanopolis -pływające miasto, mające znaleźć się na Pacyfiku, w Polinezji Francuskiej https://futurism.com/videos/artisanopolis-the-floating-city-of-the-future (dostęp 21.03.2018)

${ }^{4}$ Technologia opracowana przez Dominica Michaelis, Alexa Michaelin i Trevora Cooper Chadwick, S. M. Masutani and P. K. Takahashi Ocean Thermal Energy Conversion (OTEC), 2001 Academic Press s. 19941999, http://www.curry.eas.gatech.edu/Courses/6140/ency/Chapter2/ Ency_Oceans/OTEC.pdf, (dostęp 21.03.2018)

5 R. Maitland: Tourism in National Capitals and Global Change. Routledge, 2014, s. 57

${ }^{6}$ K. Dovey Fluid City. Transforming Melbourne's Urban Waterfront. A UNSW Press Book. 2005, s. 19

7 /bidem, s.23

8 Ibidem, s. 16

${ }^{9}$ https://www.planning.vic.gov.au/, (dostęp 12.03.2018)

10 Projekt dyplomowy, autor: Kinga Żuk, promotor: dr hab. inż. arch. Magdalena Jagiełło-Kowalczyk, prof.PK, współpromotor: dr inż. arch. Bogdan Siedlecki, Wydział Architektury Politechniki Krakowskiej, Kraków 2017

${ }^{11}$ D. Wantuch-Matla. Przestrzeń Publiczna 2.0. Miasto u progu XXI wieku. Dom Wyd. Księży Młyn. 2016, s.196

12 Project for Public Spaces (PPS) to organizacja nonprofit, zajmująca się planowaniem przestrzennym, projektowaniem oraz badaniami, edukacja związana z przestrzeniami publicznymi, https://www.pps.org/ (dostęp 26.03.2018)

1310 Qualities of a Great Waterfront Destination, Jan 1 2009, https:// www.pps.org/article/10-qualities-of-a-great-waterfront, (dostęp 26.03.2018)

\section{LITERATURA}

[1] vincent.callebaut.org/

[2] http://inhabitat.com/lilypad-floating-cities-in-the-age-of-global-war-

[3] https://futurism.com/videos/artisanopolis-the-floating-city-of-the-future

[4] S. M. Masutani and P. K. Takahashi Ocean Thermal Energy Conversion (OTEC), 2001 Academic Press s. 1994-1999, http://www.curry.eas. gatech.edu/Courses/6140/ency/Chapter2/Ency_Oceans/OTEC.pdf,

[5] R. Maitland: Tourism in National Capitals and Global Change. Routledge, 2014

[6] K. Dovey Fluid City. Transforming Melbourne's Urban Waterfront. A UNSW Press Book. 2005,

[7] https://www.planning.vic.gov.au/,

[8] D. Wantuch-Matla. Przestrzeń Publiczna 2.0. Miasto u progu XXI wieku. Dom Wyd. Księży Młyn. 2016

[9] https://www.pps.org/(dostęp 26.03.2018)

[10] 10 Qualities of a Great Waterfront Destination, Jan 12009 , https://www. pps.org/article/10-qualities-of-a-great-waterfront, (dostęp 26.03.2018) sary to provide good connections through both personal, public and marine transport.

Water attracts people, it is a significant factor that increases the attractiveness of waterfronts, however, public spaces often require the creation of a certain identity, an identifying factor that is memorable. This identification can be aided by an interesting urban design, street furniture, lighting or an iconic building. All of these factors affect the perception of space, its attractiveness and degree of the use of the site-specific potential of a given place. Modern artificial island structures have made this development of waterfront areas possible, in addition to the creation of an iconic image of a city which opens itself up before the ships sailing to port. It appears that the Port Phillip Bay artificial island, which rises up to these challenges, would make it possible for Melbourne to gain a new quality as well.

\section{ENDNOTES}

1 vincent.callebaut.org/ (retrieved on 21.03.2018)

2 Lily Pad a futuristic floating city by Vincent Callebaut http://inhabitat. com/lilypad-floating-cities-in-the-age-of-global-warming , (retrieved on 21.03.2018)

${ }^{3}$ Artisanopolis afloating city that is meant to be located in the Pacific Ocean, in French Polynesia https://futurism.com/videos/artisanopolis-the-floating-city-of-the-future (retrieved on 21.03.2018)

4 Technology developed by Dominic Michaelis, Alex Michaelin and Trevor Cooper Chadwick, S. M. Masutani and P. K. Takahashi Ocean Thermal Energy Conversion (OTEC), 2001 Academic Press p. 19941999, http://www.curry.eas.gatech.edu/Courses/6140/ency/Chapter2/Ency Oceans/OTEC.pdf, (retrieved on 21.03.2018)

5 R. Maitland: Tourism in National Capitals and Global Change. Routledge, 2014, p. 57

${ }^{6}$ K. Dovey Fluid City. Transforming Melbourne's Urban Waterfront. A UNSW Press Book. 2005, p. 19

7 /bidem, p.23

8 Ibidem, p. 16

${ }^{9} \mathrm{https}$ ://www.planning.vic.gov.au/, (retrieved on 12.03.2018)

10 Diploma project, author: Kinga Żuk, supervisor: dr hab. inż. arch. Magdalena Jagiełło-Kowalczyk, prof. PK, co-supervisor: dr inż. arch. Bogdan Siedlecki, Faculty of Architecture of the Cracow University of Technology, Krakow 2017

11 D. Wantuch-Matla. Przestrzeń Publiczna 2.0. Miasto u progu XXI wieku. Dom Publ. Księży Młyn. 2016, p.196

12 Project for Public Spaces (PPS) is a non-profit organisation focusing on spatial planning, design and research, as well as education associated with public spaces, https://www.pps.org (retrieved on 26.03.2018)

1310 Qualities of a Great Waterfront Destination, Jan 1 2009, https:// www.pps.org/article/10-qualities-of-a-great-waterfront, (retrieved on 26.03.2018)

\section{BIBLIOGRAPHY}

[1] vincent.callebaut.org/

[2] http://inhabitat.com/lilypad-floating-cities-in-the-age-of-global-warming ,

[3] https://futurism.com/videos/artisanopolis-the-floating-city-of-the-future

[4] S. M. Masutani and P. K. Takahashi Ocean Thermal Energy Conversion (OTEC), 2001 Academic Press p. 1994-1999, http://www.curry. eas.gatech.edu/Courses/6140/ency/Chapter2/Ency_Oceans/OTEC. pdf,

[5] R. Maitland: Tourism in National Capitals and Global Change. Routledge, 2014

[6] K. Dovey Fluid City. Transforming Melbourne's Urban Waterfront. A UNSW Press Book. 2005,

[7] https://www.planning.vic.gov.au/,

[8] D. Wantuch-Matla. Przestrzeń Publiczna 2.0. Miasto u progu XXI wieku. Dom Publ. Księży Młyn. 2016

[9] https://www.pps.org/ (retrieved on 26.03.2018)

[10] 10 Qualities of a Great Waterfront Destination, Jan 12009 , https:// www.pps.org/article/10-qualities-of-a-great-waterfront, (retrieved on 26.03.2018) 
RZUT PARTERU 1:200
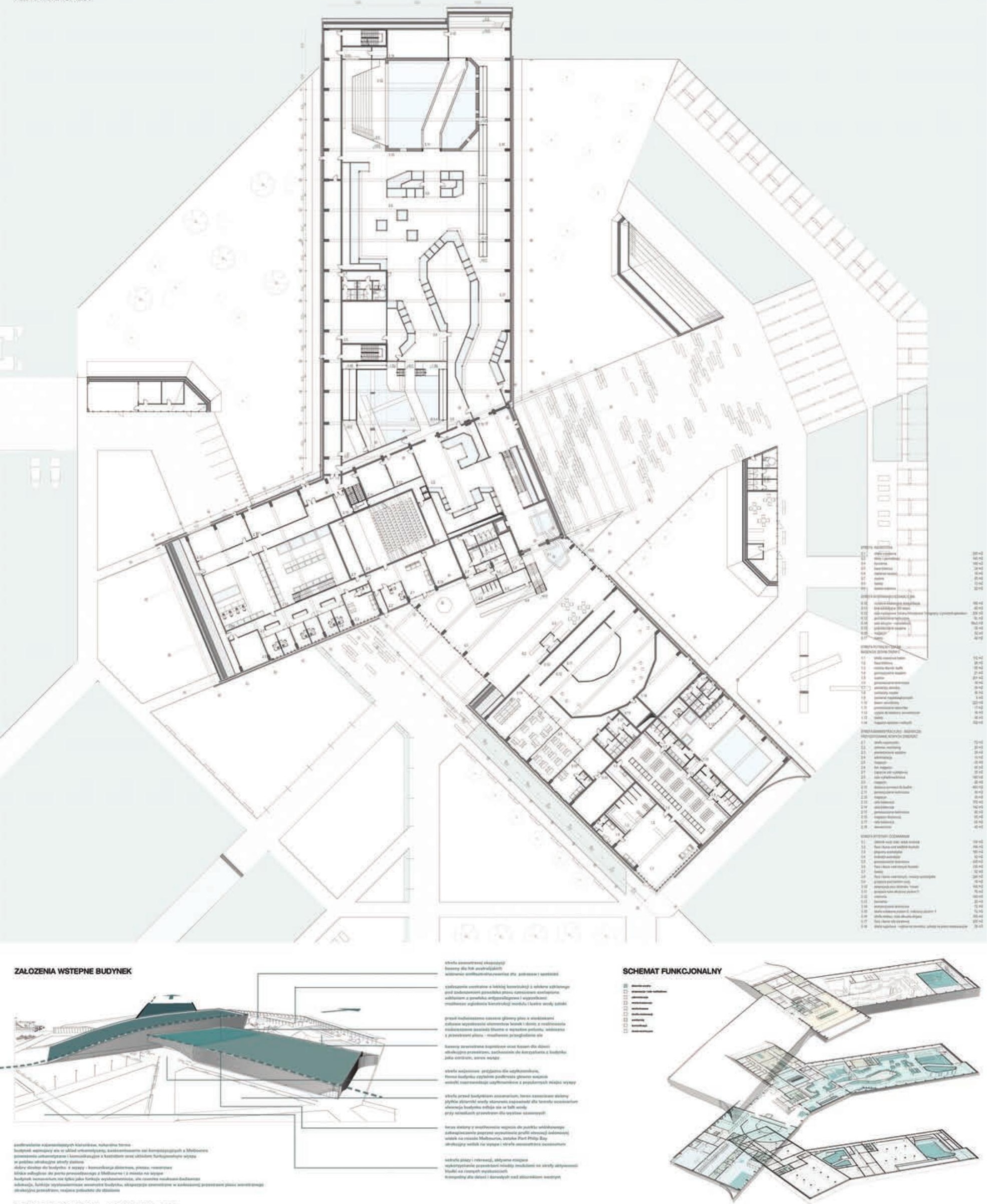


\section{MELBOURNE . PORT . OCEANARIUM}

SCHEMAT KOMUNIKACJA

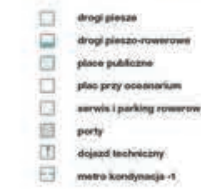

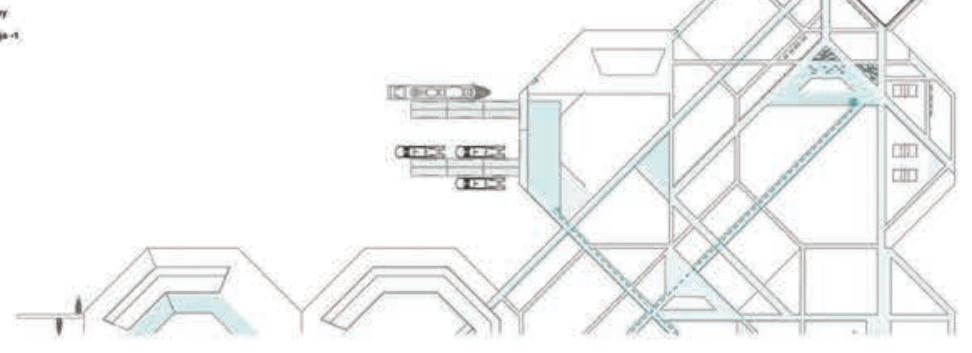

SCHEMAT FUNKCJONALNY

$=$
$\bar{z}$
$\bar{z}$
$\bar{z}$

,

SCHEMAT INSTALACJE

-

$=$

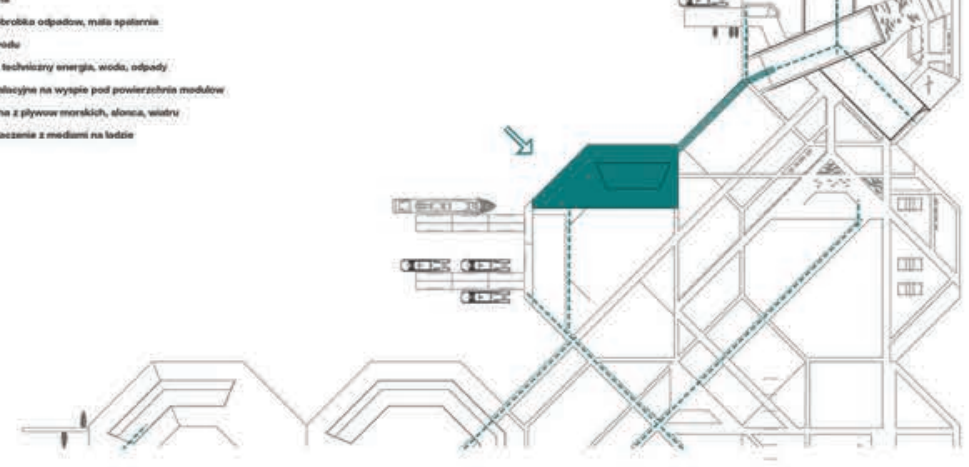

BUDYNEK SCHEMAT POWIAZAN

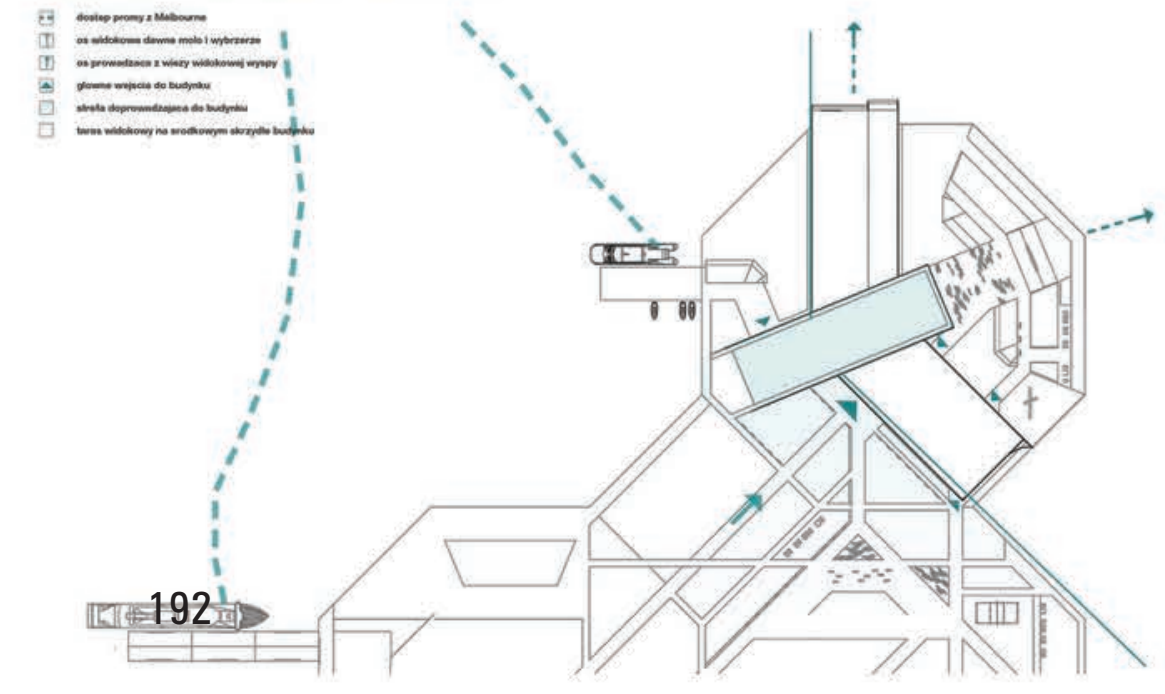

ZAGOSPODAROWANIE TERENU

SKALA 1:100

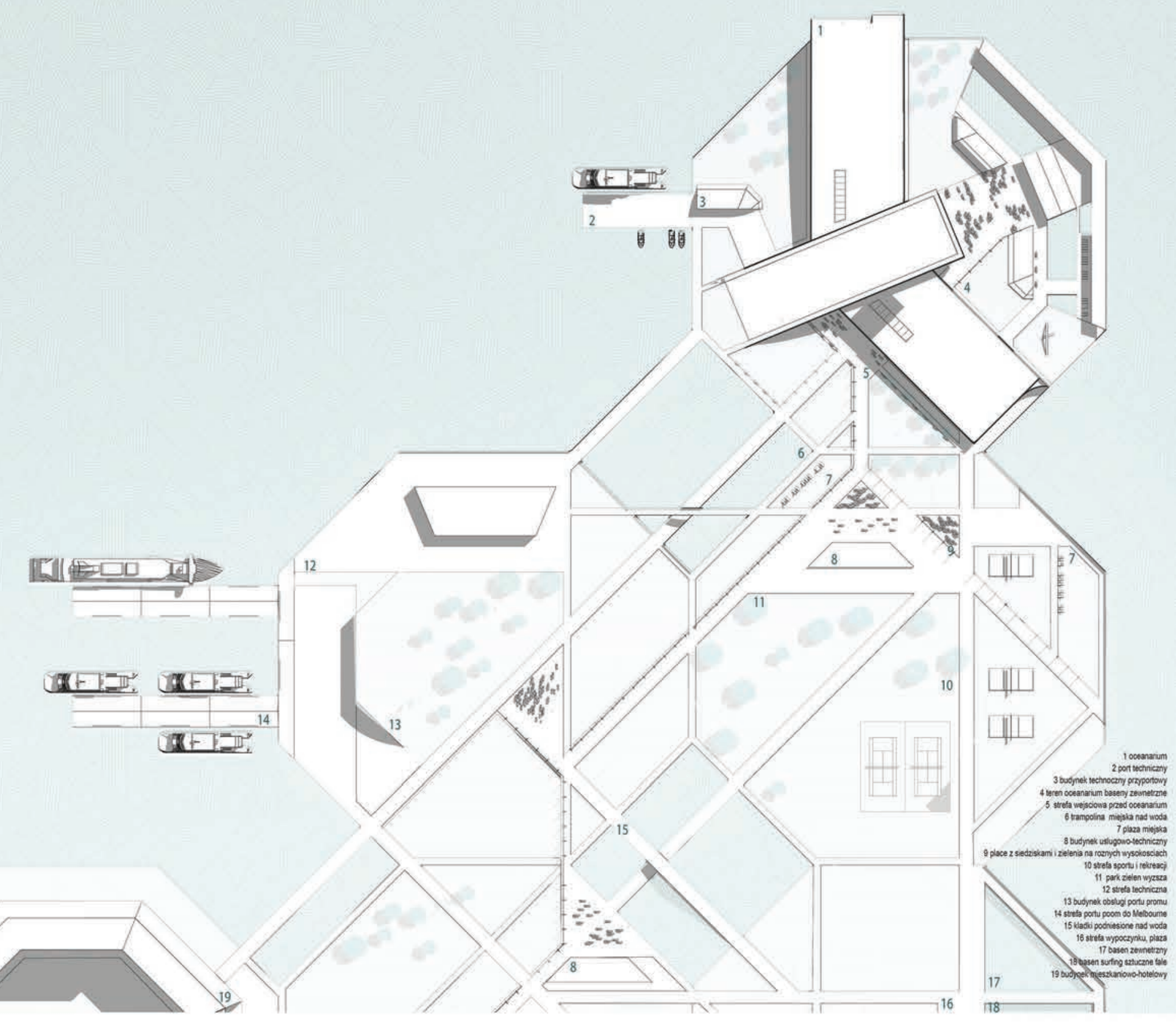

PRZEKRÓJ TERENU 1:1000

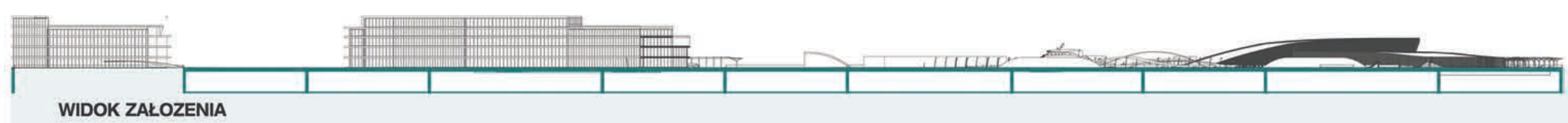

WIDOK ZAKOZENIA
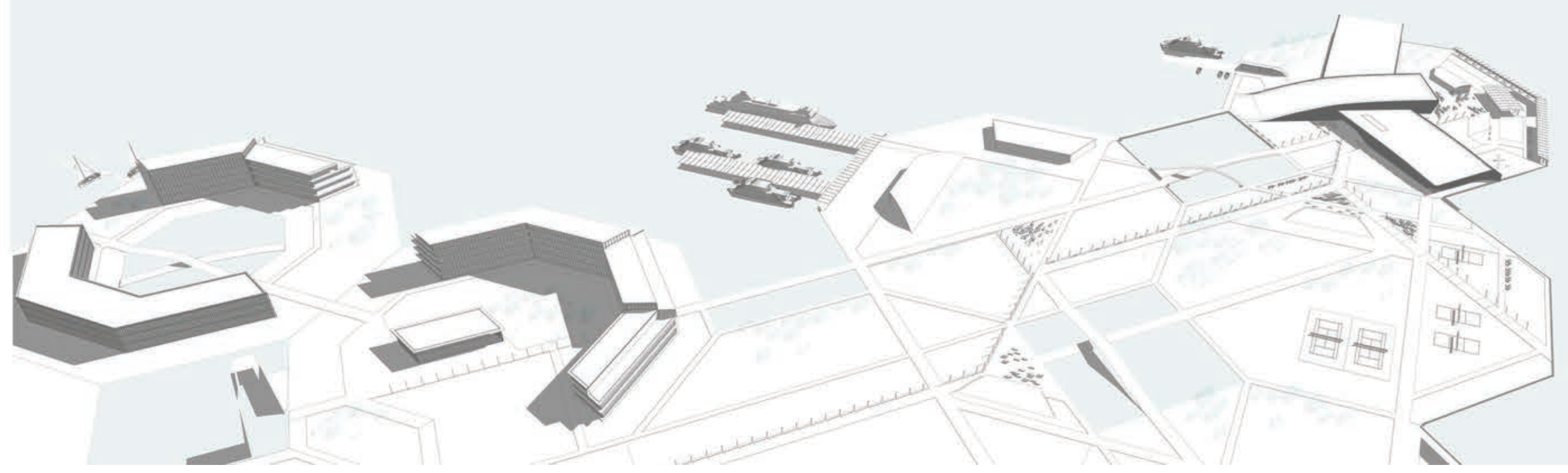
MELBOURNE . PORT . OCEANARIUM

SCHEMAT FUNKCJONALNY, PROPOZYCJA UKLADU URBANISTYCZNEGO
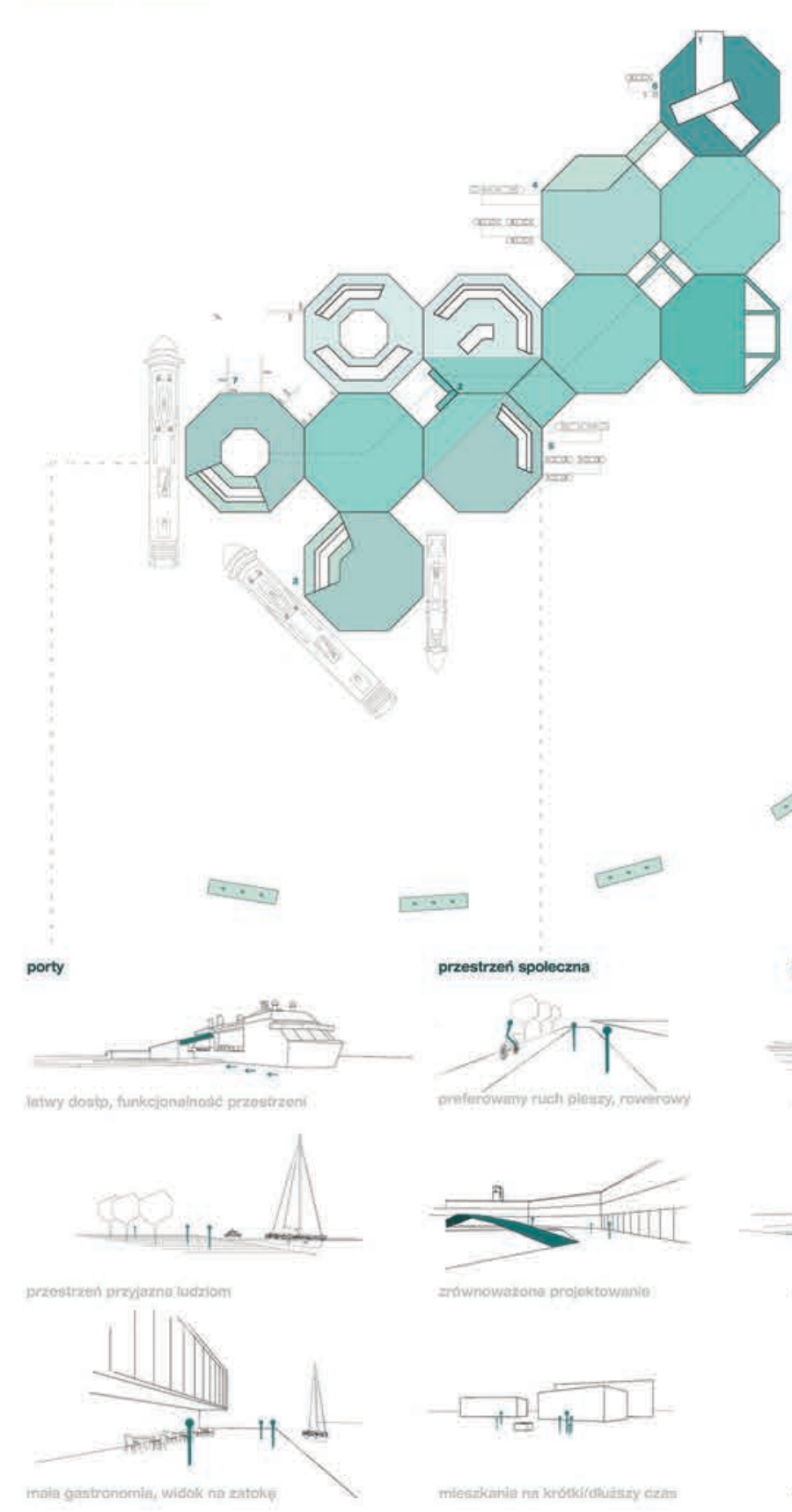

PROPONOWANE ROZWIAZANIA TECHNOLOGICZNE

Cr

$$
\begin{aligned}
& 71 \\
& 0 \\
& 0
\end{aligned}
$$

$\underbrace{1}_{0=0}$
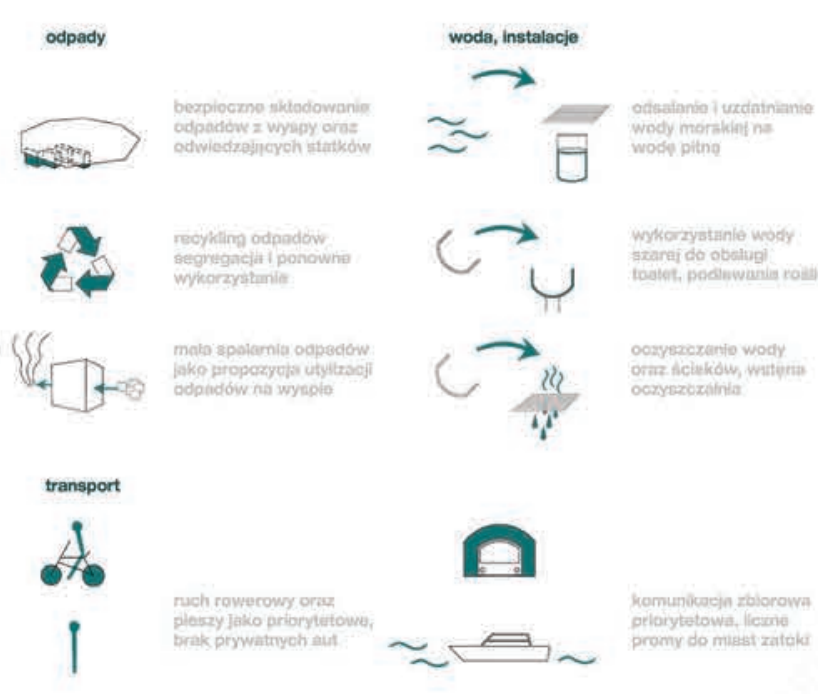

口
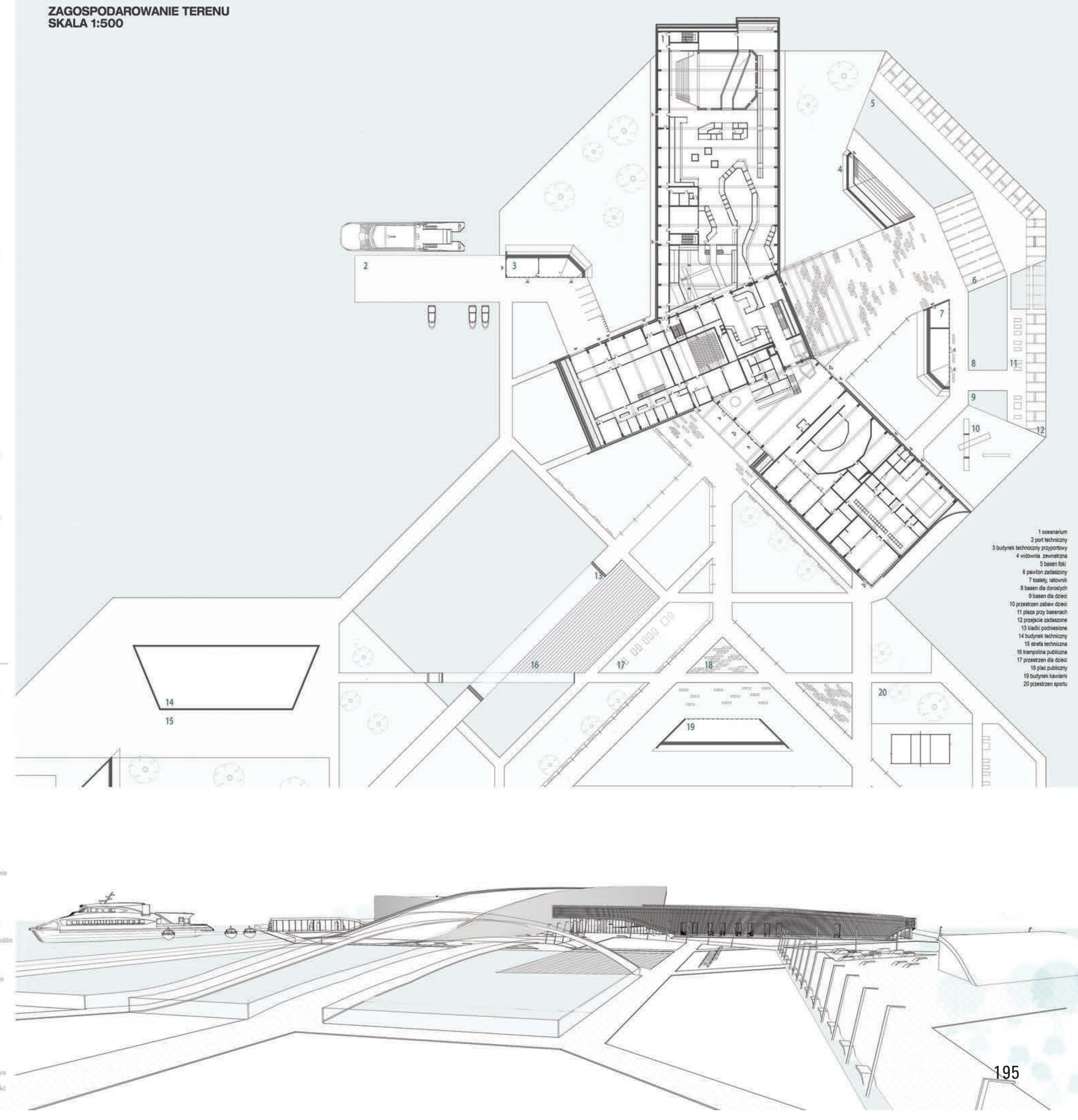

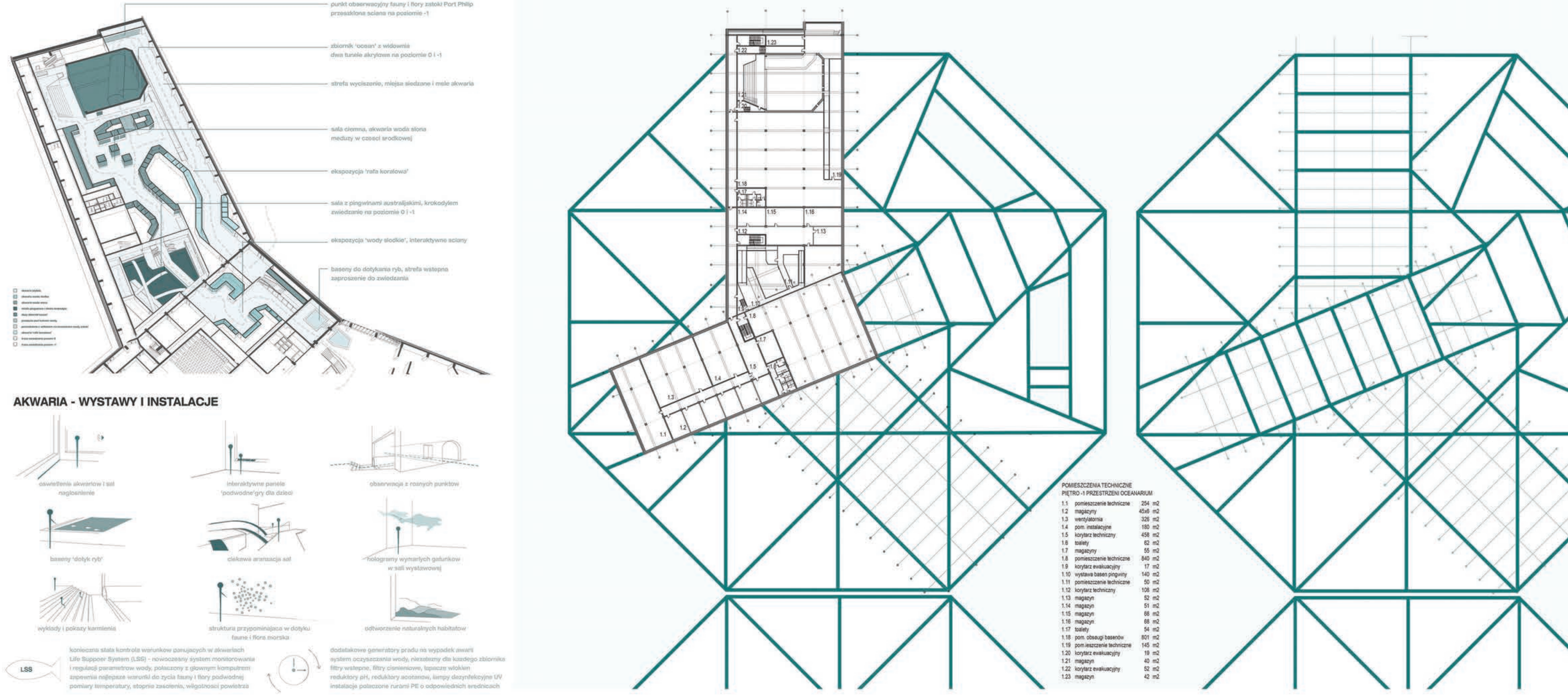

AKWARIA - WYSTAWY I INSTALACJE

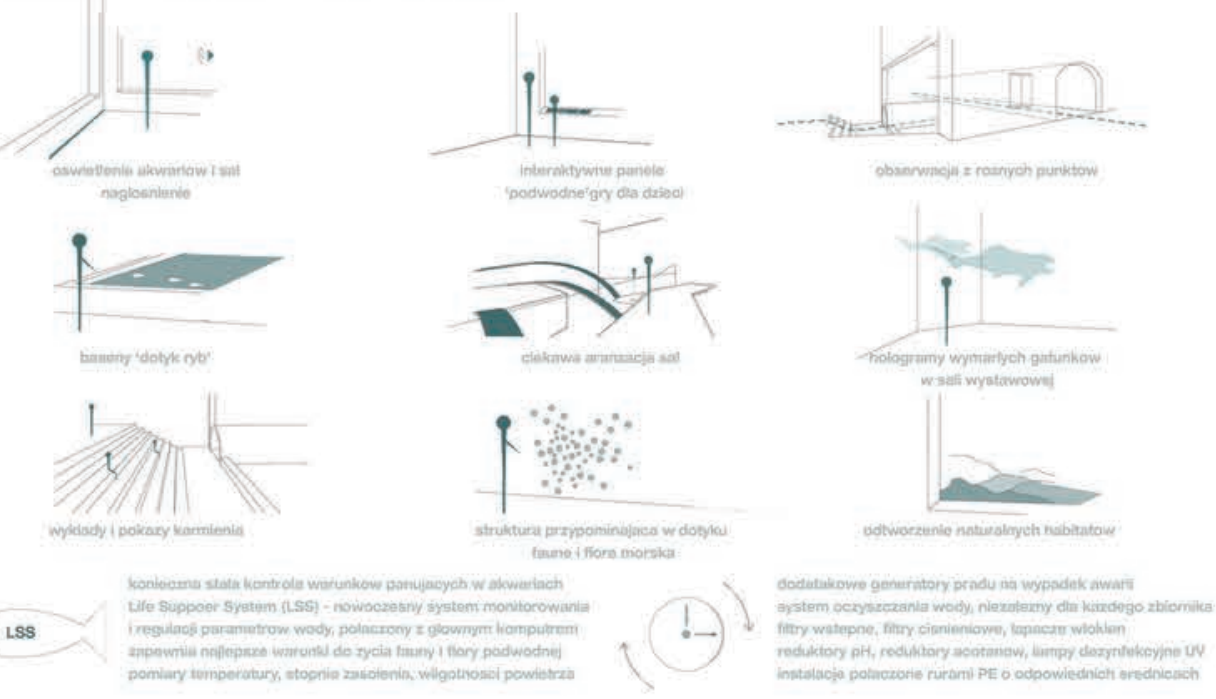

ELEWACJA POKUDNIOWO-ZACHODNIA 1:200 
